\title{
Požari na plovilima
}

\section{Fires on Vessels}

Nenad Papić

Samostalni vještak za tehnička vještačenja

Centra "Ivan Vučetić" i sudski vještak

Zagreb

E-mail:npapic@mup.hr, npapic59@gmail.com

\section{Sažetak}

U članku se na primjerima iz prakse prikazuje rad vještaka Centra za forenzična ispitivanja, istraživanja i vještačenja „Ivan Vučetić“ (CFIIV „Ivan Vučetić") prilikom utvrđivanja uzroka požara na plovilima. Iznose se metode utvrđivanja mjesta nastanka i uzroka požara te se ukazuje na uočene nepravilnosti i karakteristične kvarove koji mogu dovesti do požara. Prikazuju se uobičajene izvedbe elektroinstalacija na plovilima i moguće opasnosti od strujnog udara. Opisuje se utjecaj struje na ljudsko tijelo, kao i granične struje i naponi dodira. Prilikom priključka plovila kabelom na mrežu ukazuje se na mogućnosti zaštite od udara električne struje. U radu opisuje se više stvarnih slučajeva požara u kojima se navode neki karakteristični kvarovi kao mogući uzroci požara na plovilima te se iznose rezultati vještačenja uzroka požara na plovilima. Rad je prvenstveno namijenjen kolegama koji se bave istraživanjem uzroka požara, djelatnicima pravosuđa i policije, a također i svima drugima koji se bave nautikom i plovilima. Cilj je rada dati doprinos popunjavanju stručne literature iz ovoga nedovoljno obrađenog, a vrlo zanimljivog područja.

\section{Summary}

The paper describes real cases of fires on board as well as investigation and determination of fire causes by experts from Forensic Science Centre "Ivan Vučetić" (FSC Ivan Vučetić). The methods of determining the causes of fire are described and characteristic defects that may cause fire are pointed out. Conventional wiring diagrams are displayed on vessels, indicating potential electric shock hazards. The impact of electric current onto the human body is described, also the boundary current and the contact voltages are given. When connecting the vessel with a cable to the power grid, the possibilities of protection against electric shock are discussed. Several real cases of fire are described in which some characteristic faults are mentioned as possible causes of fire and some results of the investigations are given. The aim of the paper is to attract the attention of the colleagues who are researching the causes of fire breakouts, such as investigators and experts, and others who are engaged in navigation and vessels. The aim is to contribute to the scientific literature in this insufficiently analysed yet very interesting area.
DOI 10.17818/NM/2020/3.10

UDK614.841.48:656.61

Stručni rad / Professional paper

Rukopis primljen / Paper accepted: 15. 1. 2019.

\begin{tabular}{|l} 
KLJUČNE RIJEČI \\
požari \\
vještaci \\
uzrok požara \\
plovila \\
strujni udar
\end{tabular}

KEY WORDS

fires

experts

cause of fire

vessels

electric shock

\section{UVOD / Introduction}

Utvrđivanje uzroka požara kombinirano je vještačenje koje se provodi pregledom opožarenih objekata, vozila, plovila i drugog od strane vještaka Centra za forenzična ispitivanja, istraživanja i vještačenja „Ivan Vučetić", a vještačenjem se primarno utvrđuje je li do požara došlo uslijed tehničkog kvara ili nepravilnosti ili se, pak, radi o namjerno izazvanom požaru - paljevini.

Postupak vještačenja požara, ako se radi o električnoj energiji kao mogućem uzroku, provodi se pregledom i ispitivanjem električnih instalacija i električnih uređaja, utvrđivanjem mjesta nastanka i vrste kvara na dijelu električne instalacije ili na električnom uređaju te utvrđivanjem veze između kvara i uzroka požara. Postupakse provodi očevidom mjesta događaja i vještačenjem materijala vještačenja izuzetog na mjestu događaja požara. Predmet su vještačenja požari u objektima, postrojenjima, na vozilima, plovilima i drugom.

Vještaci Centra "Ivan Vučetić" u svojem dosadašnjem radu vještačili su požare različitih plovila u marinama, ali su predmet rada vještaka bili i požari na plovilima prilikom plovidbe radi utvrđivanja uzroka požara, odnosno zbog sumnje da se radi o podmetnutim požarima. Također, radila su se vještačenja uzroka požara do kojih je došlo u brodogradilištu, kada su predmet vještačenja bili požari koji su nastali prilikom radova na novogradnji i remontu broda.

U članku se ukratko prikazuju električne instalacije na plovilima, način priključenja plovila na mrežu $220 \mathrm{~V}$ na kopnu te se s obzirom na opasnosti od strujnog udara opisuje djelovanje struje na ljudski organizam i zaštita od strujnog udara.

Opisuje se vještačenje uzroka požara na plovilima te se donose primjeri stvarnih slučajeva požara koji su bili predmet rada vještaka. Na kraju iznose se neki karakteristični kvarovi na električnoj instalaciji i uređajima na plovilima koji su mogući uzroci požara.

\section{BRODSKA INSTALACIJA / Vessel installation}

2.1. Priključak broda na kopno / Power connection of vessels to the mainland

Pregled električnih instalacija i električnih uređaja plovila radi utvrđivanja kvara ili nedostataka na njima kao mogućeg uzroka požara plovila vrši se slično pregledu drugih sustava za napajanje električnom energijom: od izvora napajanja (mreže izmjenične struje $220 \mathrm{~V}$ ili akumulatora - izvora istosmjerne struje $12 \mathrm{~V}$ ili $24 \mathrm{~V}$ ), preko prijenosa (električnih kabela) do pojedinih trošila (električnih uređaja). Pri tome je potrebno utvrditi što je u vrijeme požara od navedenog sustava bilo pod naponom. Kada je plovilo u kretanju, većina je električnih kabela i trošila pod naponom, dok u stanju mirovanja, dok je plovilo na vezu ili suhom vezu, treba utvrditi je li plovilo priključeno na priključni ormarić napajanja 220V izmjenične struje ili je ono na akumulatorskom napajanju postoji li na plovilu sustav napajanja solarnom energijom. Ovisno o navedenim načinima napajanja, s pomoću tehničke dokumentacije plovila 
treba utvrditi koji su strujni krugovi na plovilu bili pod naponom.

Pregledom priključnog ormarića mrežnog napajanja (220 V izmjenične struje), koje se nalazi na vezu ili suhom vezu, može se utvrditi je li plovilo bilo priključeno na napajanje $220 \mathrm{~V}$, a pregledom zaštitnih elemenata u razvodnom ormariću može se utvrditi stanje zaštitne sklopke i osigurača, na temelju čega se može zaključiti o električnom stanju strujnih krugova $220 \mathrm{~V} \mathrm{u}$ trenutku nastanka požara.

U marinama koriste se standardne izvedbe priključnih ormarića, od kojih je jedan od tipova prikazan na slici.
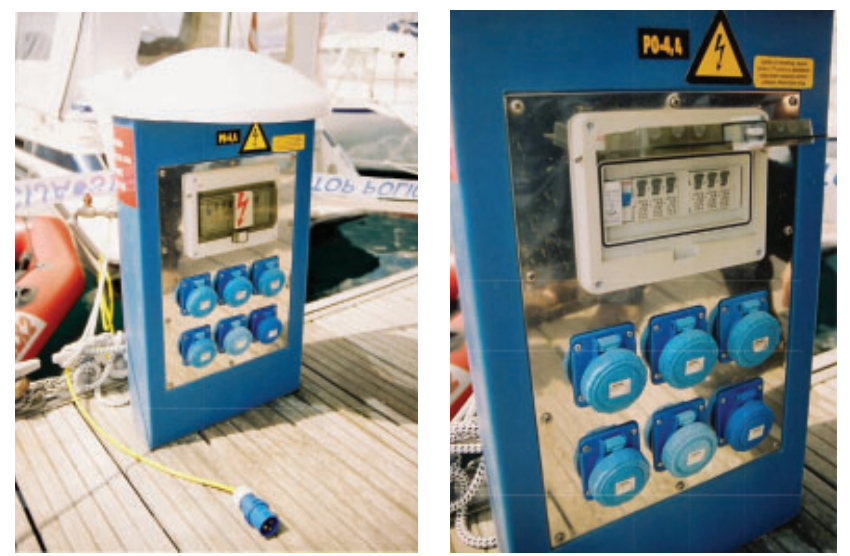

Slika 1. Opći i bliži izgled priključnog ormara u marini

Figure 1 General and close view of electrical cabinet in marina Izvor: CFIIV „Ivan Vučetić“, fotografije s očevida

Osnovni krug elektroinstalacije plovila, kao i u slučaju vozila, sastoji se od baterije koja se zakretanjem kontaktnog ključa spaja na elektropokretač motora. Na navedenu instalaciju spojen je alternator, čija je zadaća punjenje baterije tijekom rada motora plovila (vozila). Osim startne baterije, na plovilu obično postoji još jedna dodatna baterija (kućna baterija), koja služi za napajanje trošila koja se nalaze na plovilu. Za punjenje baterije kada motor plovila ne radi koristi se fotonaponski modul i odgovarajući punjač, a kada se plovilo nalazi u marini, baterija se može puniti iz električne mreže 220 V, $50 \mathrm{~Hz}$, spajanjem s pomoću električnog kabela na priključni ormarić. Također, postoji mogućnost napajanja, odnosno punjenja baterije s pomoću generatora ako se on nalazi na plovilu. Dalje od baterije trošila se napajaju istosmjernom strujom, a s pomoću izmjenjivača omogućeno je napajanje izmjeničnih trošila.

\subsection{Djelovanje struje na čovjeka / Impact of electrical current onto the human body}

Elektrokucija je svjesno ili nesvjesno izlaganje čovjeka djelovanju električnestruje.Zadjelovanjeelektričnestrujenačovjekanajvažnija je jakost električne struje (Tablica 1.). Razlikuju se otpuštajuća struja - najveća struja pri kojoj se čovjek još može snagom svojih mišića odvojiti od dijelova pod naponom, fibrilacijska struja - ona jakost struje pri kojoj u nekih ljudi može nastupiti smrt i nefibrilacijska struja - čijim se djelovanjem ne može izazvati smrt.

Tablica 1. Djelovanje električne struje ovisno o jakosti struje Table 1 Impact of electrical current depending on the input power

\begin{tabular}{|c|c|}
\hline Jakost struje & Djelovanje struje \\
\hline 10 do $16 \mathrm{~mA}$ & Otpuštajuća \\
\hline$<50 \mathrm{~mA}$ & Nefibrilacijska \\
\hline 50 do $100 \mathrm{~mA}$ & Opasna za život \\
\hline$>100 \mathrm{~mA}$ & Fibrilacijska \\
\hline
\end{tabular}

Izvor: Srb, 1991.
Električna struja opasna je za ljudsko tijelo kada prilikom dodira dijelova pod naponom kroz tijelo ili dio tijela teče električna struja i ljudsko tijelo postaje dio zatvorenog strujnog kruga. To se događa kada čovjek dođe u dodir s metalnim dijelom (kućištem) električnog uređaja koje je došlo pod napon zbog greške na izolaciji ili na neki drugi način.

Veličina struje koja prolazi kroz ljudsko tijelo određena je Ohmovim zakonom: I = U/Z, gdje su:

I- struja koja protječe kroz tijelo (A)

$\mathrm{U}$ - napon dodira $(\mathrm{V})$

Z - impedancija ljudskog tijela $(\Omega)$.

U praksi govori se o otporu ljudskog tijela koji se sastoji od unutarnjeg otpora i otpora kože. Unutarnji otpor tijela iznosi 500 do $750 \Omega$, što ovisi o masi ljudskog tijela, a obično se uzima da je otpor ljudskog tijela $1300 \Omega$ pri $220 \mathrm{~V}$ i $50 \mathrm{~Hz}$.

Otpor ljudskog tijela ovisi o: vlažnosti (znojenju) kože, muskulaturi, trajanju djelovanja, visini napona, vrsti struje, frekvenciji, temperaturi tijela (pri fizičkom naporu otpor je manji), duševnom stanju (u euforičnom stanju otpor je manji) i drugom.

Za djelovanje struje na čovjeka važan je put struje kroz tijelo, a najopasniji je put kroz srce, do čega dolazi kada struja prolazi putem: ruka - ruka i ruka - noga, stoga oko $90 \%$ smrtnih slučajeva nastaje pri dodiru dijelova pod naponom jednom rukom, dok je druga ruka ili noga bila dobro uzemljena.

Granice opasnih napona određene su propisima na temelju djelovanja struja različitih jakosti i prosječne impedancije ljudskog tijela (Mileusnić, 1999.). Za normalne uvjete okoline i rada trajno dopušteni je napon dodira onaj manji od $50 \mathrm{~V}$ za izmjeničnu struju i napon manji od $120 \mathrm{~V}$ za istosmjernu struju. Za teže uvjete rada i okoline (vlaga i drugo) propisani su granični napon dodira od $25 \mathrm{~V}$ za izmjeničnu struju i $60 \mathrm{~V}$ za istosmjernu struju.

\subsection{Zaštita od strujnog udara / Protection against electric shock}

Do strujnog udara, koji može imati i smrtne posljedice, može doći direktnim (izravnim) dodirom s dijelovima pod naponom, koji može nastati zbog:

nepropisno položenih golih (neizoliranih) električnih vodiča oštećene izolacije na vodičima i priključnim instalacijama.

Također, do strujnog udara može doći indirektnim (neizravnim) dodirom dijelova pod naponom kao posljedica kvara na izolaciji električnih uređaja.

Do strujnog udara dolazi tako što čovjek dodirne metalni dio (kućište uređaja) koje je zbog oštećene ili neispravne izolacije poprimilo određen napon prema zemlji i istovremeno dodirom drugog, uzemljenog dijela na plovilu zatvori strujni krug kada nastaje razlika potencijala koja uzrokuje protjecanje električne struje kroz tijelo.

Jedan od mogućih načina zaštite od neizravnog dodira kućišta trošila koje je zbog kvara došlo pod napon izvodi se automatskim isključenjem napajanja. Zaštita elektroinstalacija izvodi se zaštitnim prekidačima (automatskim osiguračima) i zaštitnom strujnom sklopkom, koji se ugrađuju u priključni ormarić u marini. Zaštitni prekidač ima dva stupnja zaštite: zaštita od preopterećenja i zaštita od kratkog spoja. Zaštitna je sklopka zaštitni uređaj diferencijalne struje (RCD sklopka, engl. Residual Current Device, ranije se koristio naziv FID sklopka ili "fidovka“), koja štiti svaki priključak na priključnom ormariću u slučaju kvara na izolaciji priključenih trošila, ali ona ne isključuje struju kratkog spoja. Danas postoje i uređaji koji su kombinacija zaštitnog prekidača i zaštitne sklopke, 


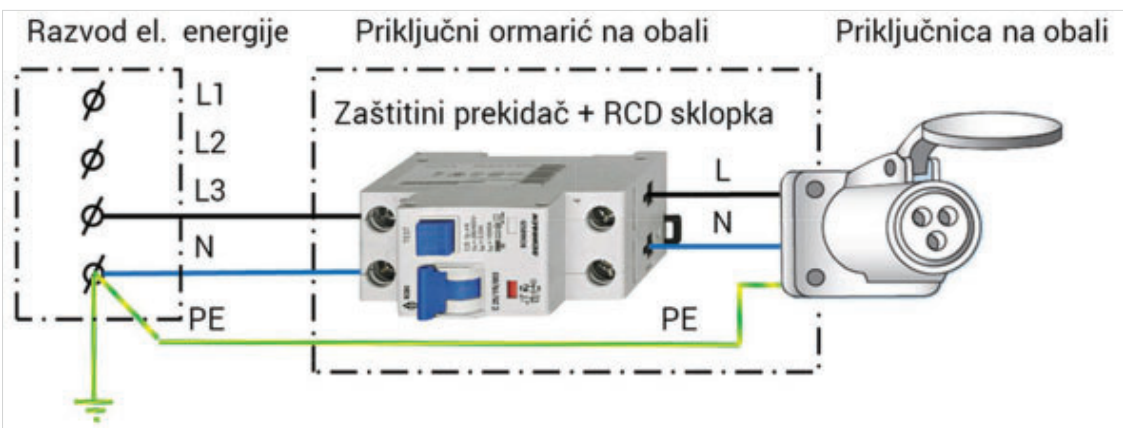

Slika 2. Spoj priključnice u priključnom ormariću na obali u marini Figure 2 Connection in the electrical cabinet in the marina

Izvor: https://www.burzanautike.com/hr/prikljucak_na_kopno/4051/25

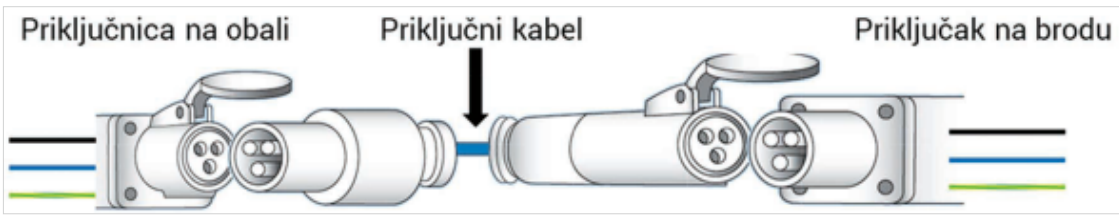

Slika 3. Priključni kabel za spajanje plovila i kopna

Figure 3 Cable connecting the vessel with the mainland

Izvor: https://www.burzanautike.com/hr/prikljucak_na_kopno/4051/25

takozvani kombinirani prekidači, koji objedinjuju funkcije obaju navedenih zaštitnih uređaja. Elektroinstalacija i trošila u plovilu su zaštićeni zaštitnim prekidačima i zaštitnom sklopkom koji se nalaze u razvodnom ormariću u plovilu.

\subsection{Priključni kabel / Cable}

Priključni kabel kojim je plovilo priključeno na ormarić na obali, prema preporukama, ne smije biti dulji od 25 metara i ne smije imati međuspojeve na toj duljini. Brodska utičnica mora biti zaštićena od prodora kiše i polijevanja vodom ili morem i ugrađena tako da bude pristupačna, ali da pri normalnoj komunikaciji na brodu ne dođe do oštećenja niti utikača na brodu niti utičnice kabela.

\section{POSTUPAK VJEŠTAČENJA POŽARA NA} PLOVILIMA / Fire Investigation Procedure on Vessels

Postupak utvrđivanja uzroka požara na plovilima vrši se pregledom i ispitivanjem električnih instalacija i uređaja u različitim tipovima motornih i drugih vrsta plovila.

\subsection{Priprema za pregled mjesta događaja požara na} plovilima / Preparation for fire scene investigation on vessels Prije pregleda mjesta događaja (opožarenog plovila) treba dobiti sve dostupne obavijesti u vezi s nastankom požara, prikupiti tehničku dokumentaciju i nacrte plovila iste marke i modela kao što je opožareno plovilo te utvrditi vrstu električnog napajanja plovila.

Prije pregleda mjesta događaja (opožarenog plovila) treba utvrditi sljedeće činjenice:

mjesto i vrijeme nastanka požara

tko je oštećeni (vlasnik ili korisnik plovila)

vrstu plovila i godinu gradnje, marku i model plovila te reg. oznaku plovila

tehničke karakteristike plovila: broj, tip i snagu motora, dimenzije (duljinu, širinu i dubinu gaza) te masu plovila od očevidaca događaja treba dobiti obavijesti o vremenu zapažanja i opisu događaja, a ako postoje, pregledati snimljene fotografije i videozapise požara

- vrijeme dojave požara i vrijeme dolaska vatrogasaca od vatrogasaca dobiti obavijesti o opisu tijeka i gašenja požara, a ako postoje, pregledati snimljene fotografije i videozapise prilikom gašenja požara

- pregledati videozapise nadzornih kamera

- prikupiti tehničku dokumentaciju i nacrte plovila iste marke i modela kao što je opožareno plovilo

- $\quad$ izvršiti usporedan pregled plovila iste marke i modela kao što je opožareno plovilo ako je ono na raspolaganju u luci ili marini utvrditi u kojem je pogonskom stanju bilo plovilo prije izbijanja požara:

- je li plovilo bilo u stanju mirovanja na vezu, suhom vezu ili u vožnji

- utvrditi vrstu napajanja plovila:

- je li plovilo bilo priključeno na napajanje 220 V izmjenične struje

- je li plovilo bilo priključeno na baterije (12 V ili $24 \mathrm{~V}$ istosmjerne struje)

- jeli plovilo imalo solarno napajanje fotonaponskim modulima.

Ako je opožareno plovilo (ili više njih) uslijed oštećenja tijekom požara potonulo u more, prije pregleda mjesta događaja treba izvršiti vađenje potonulih plovila. Također, treba izvršiti vađenje svih dijelova plovila koji su ispali iz plovila i potonuli na dno mora. Nakon vađenja plovila, ako se radi o više opožarenih plovila koja su bila na vezu, treba ih prema utvrđenom redoslijedu posložiti istim redom kao što su plovila bila vezana u marini.

\subsection{Postupanje prilikom očevida na plovilima / Procedure during investigation on vessels}

Prilikom pregleda plovila i ispitivanja električne instalacije u plovilu treba provjeriti je li priključni kabel $220 \mathrm{~V}$ odspojen s priključnog ormarića. Također, treba provjeriti jesu li s priključaka akumulatorske baterije odspojene stezaljke priključnih kabela.

Vizualnim pregledom treba utvrditi termička oštećenja na vanjskom dijelu trupa plovila, termička i mehanička oštećenja konopa za vezanje plovila i bokobrana, termička oštećenja u strojarnici, putničkom prostoru (kabini i drugim prostorijama) i na komandnom mostu plovila. 
Detaljnim pregledom treba utvrditi termička oštećenja na akumulatorskim baterijama i električnoj instalaciji koja vodi od akumulatora na elektropokretač, alternator, kaljužnu pumpu i razvodne ormariće u plovilu.

Detaljnim pregledom treba utvrditi termička oštećenja na kabelskim snopovima električne instalacije: kabelu napajanja izmjeničnom strujom napona $220 \mathrm{~V}$ (priključni kabel koji ide od priključnog ormarića na vezu do utičnice na plovilu) i kabelima napajanja istosmjernom strujom napona $12 \mathrm{~V}$ i $24 \mathrm{~V}$ koji se nalaze u plovilu.

Detaljnim pregledom treba utvrditi termička oštećenja na razvodnim ormarićima s osiguračima i relejima, na punjaču akumulatorskih baterija, generatoru (agregatu) i ostalim električnim uređajima.

Detaljnim pregledom treba utvrditi termička oštećenja na komandnom mostu (komandnoj ploči).

Ako je plovilo nakon požara potonulo, nakon vađenja iz mora treba utvrditi termička oštećenja na ostacima plovila i dijelovima koji su otpali s plovila.

Sva termička oštećenja na plovilu treba fotografirati, kao i sve pronađene tragove. Nakon fotografiranja treba izuzeti sporne tragove s plovila.

Postupak utvrđivanja mjesta nastanka i uzroka požara na plovilima temelji se na pronalaženju i interpretaciji tragova na mjestu događaja i opožarenom plovilu prilikom kojega vještak ispunjava Obrazac za pregled električnih instalacija i uređaja kod požara plovila. U obrascu vode se bilješke o utvrđenim tragovima (skicira se mjesto traga na crtežima plovila) i rezultatima ispitivanja.

\section{STVARNI SLUČAJEVI POŽARA NA PLOVILIMA / Real Cases of Fires on Vessels}

\subsection{Požar na plovilima na suhom vezu u marini / Fire on} vessels on dry berth in marina

Na fotografiji prikazan je požar plovila na suhom vezu u marini. Kao posljedica požara, došlo je do potpunog uništenja desetak plovila, a opožareno je dvadesetak plovila, kao što se vidi na fotografiji prije početka očevida.

Nakon dolaska u marinu dobivene su obavijesti o izjavama očevidaca požara i vatrogasaca te da je tijekom požara puhala jaka bura. Požar je nastupio oko 6 sati, a uočili su ga djelatnici marine prilikom redovitog obilaska. Marina ima videonadzor, ali on nije bio uključen u vrijeme nastanka požara.

Plovila na suhom vezu, prema obavijestima dobivenima od djelatnika marine, ne ostaju priključena na mrežno napajanje 220 V nakon 20 sati, koje je omogućeno priključkom električnog kabela na razvodni ormarić na doku, a isto kontroliraju prilikom obilaska dokova djelatnici marine i isključuju napajanje plovila koja zateknu priključena na razvodne ormariće.

Od uprave marine zatraženi su podaci o smještaju svih plovila na navedenom doku i tehnički podaci o svim plovilima. Također je zatraženo da se kontaktiraju vlasnici plovila radi dodatnih obavijesti o vrsti napajanja na njima kako bi se utvrdilo je li na njima bilo dodatno napajanje električnom energijom s pomoću solarnih panela. Na Internetu su na temelju tehničkih podataka plovila, marke i tipa plovila pronađene fotografije, crteži i drugi podaci za pojedine tipove plovila.

Prema obavijestima očevidaca i termičkim oštećenjima plovila, zaključeno je da su u požaru najviše oštećena tri plovila na sjevernoj strani doka.

Pregledom razvodnog ormarića za priključak napajanja 220 V koje se nalazi na rampi, utvrđeno je da je potpuno uništen u požaru. Na navedenom razvodnom ormariću nisu pronađeni ostaci priključenih kabela.

Pregledom jednog od spornih plovila na njemu su pronađeni tragovi taljenja na električnoj instalaciji $12 \mathrm{~V}$ mreže. Tragovi u obliku zavarivanja vodiča jednog kabela za drugi snop vodiča ukazivali su na kvar na električnoj instalaciji plovila. Prema obavijestima dobivenima od vlasnika, sporno je plovilo imalo sustav za napajanje električnom energijom s pomoću solarnih panela koji je bio u funkciji.

Nakon obavljenog očevida i pregleda svih opožarenih plovila, zaključeno je da je do požara u marini došlo na motornoj jahti koja se nalazila na sjevernoj strani suhog veza, a na temelju pronađenih materijalnih tragova zaključeno je da je uzrok požara tehnički kvar na električnoj instalaciji navedenog plovila.

\subsection{Očevid požara potonulog plovila / Investigation of fire on sunken vessel}

Na fotografiji prikazano je plovilo koje je nakon požara potonulo na dubinu od oko 80 metara te je izvađeno iz mora i dotegljeno

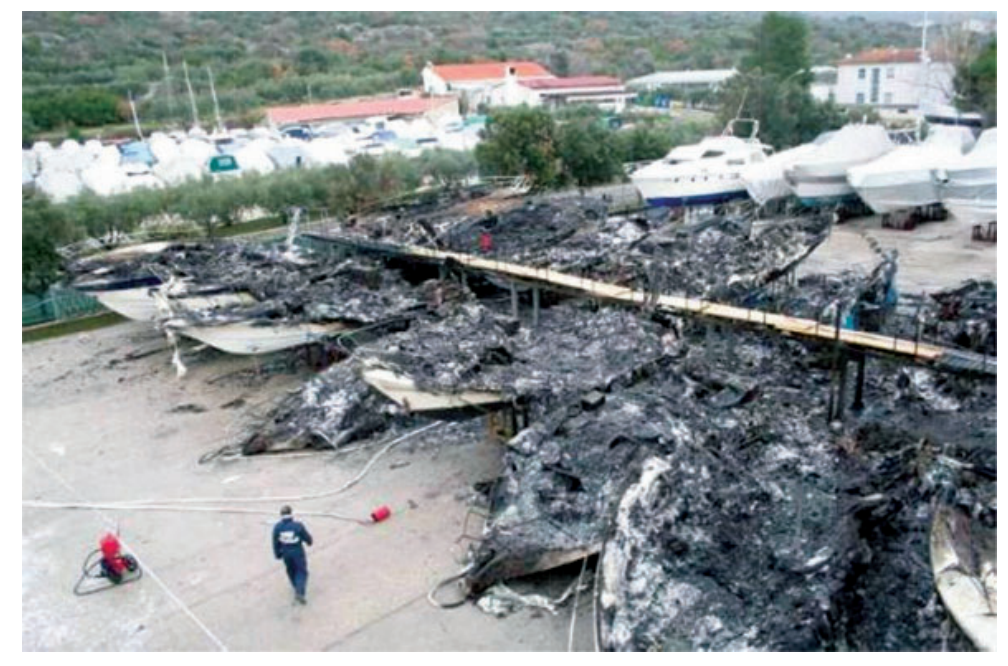

Slika 4. Posljedice požara na plovilima u marini

Figure 4 Consequences of fire on vessels in marina 


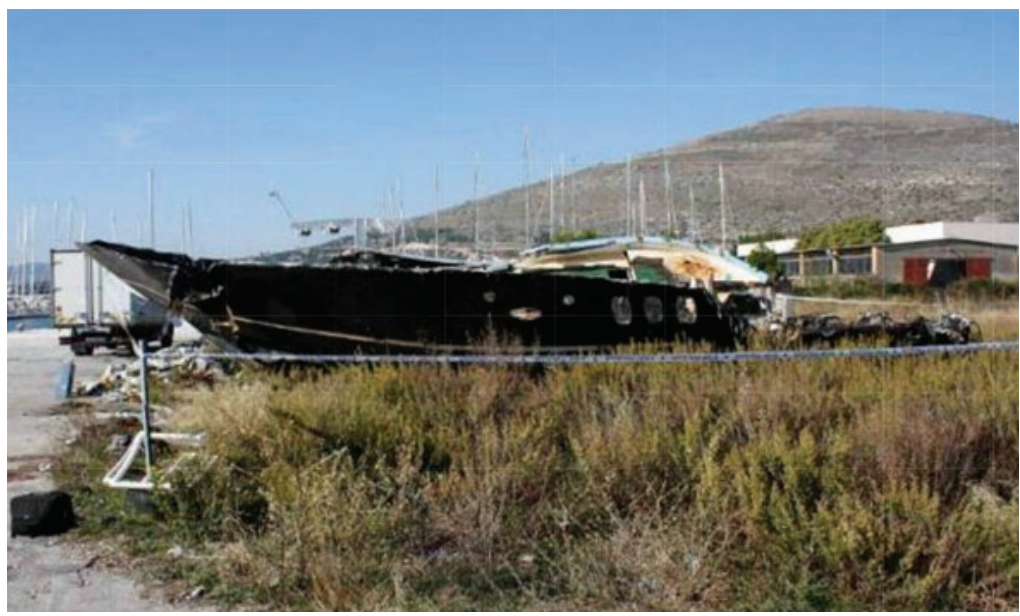

Slika 5. Potonuli brod izvađen iz mora

Figure 5 Salvage of sunken vessel from the sea

Izvor: CFIIV „Ivan Vučetić", fotografije s očevida

na obalu radi vještačenja. Navedeno je financiralo osiguravajuće društvo radi sumnje u prijevaru osiguranja. Radilo se o brodu za prijevoz putnika duljine oko 18 metara, širine oko 5 metara, visine iznad vodne linije oko 5 metara, ukupne mase oko 23 tone, sa spremnikom za gorivo od 2160 litara. Poteškoća pri vještačenju potonulih plovila nije samo u velikom termičkom uništenju - jer dolazi do gotovo potpunog gorenja dijelova trupa do vodne linije i dijelova unutrašnjosti plovila - već i u gubitku dijelova plovila prilikom potapanja. Vještačenje se radi usporednim pregledom plovila iste marke i rekonstrukcijom dijelova plovila na temelju tehničke dokumentacije.

Iz mora izvađena su dva motora potonulog broda snage 1600 KS. Na fotografiji vidi se veličina jednog od brodskih motora u usporedbi s dužinom vozila koje je bilo parkirano u blizini.

\subsection{Požar plovila u marini - slučaj 1. / Fire on vessel in marina - Case 1}

$\mathrm{Na}$ fotografiji prikazano je vađenje dijelova potonulih plovila nakon požara na plovilima u marini u kojemu je izgorjelo i potonulo ukupno 9 brodova, dok su još 2 plovila djelomično oštećena u požaru.

Prema dobivenim obavijestima, požar je primijetio jedan gost u kampu koji se nalazi u istočnom dijelu marine oko 2 sata, koji je, vjerojatno probuđen bukom nalik na eksploziju, vidio da gore plovila vezana uz ponton te je dojavio požar na broj 112 i na recepciju marine. Nakon dojave, požar su ugasili vatrogasci JVP-a i DVD-a te je lokaliziran u 4.26 sati, a potpuno je ugašen u 5.05 sati.

U popodnevni satima započelo je vađenje potonulih plovila, koja su radi očevida poslagana na obali redoslijedom kako su bila privezana na mjestu događaja požara u marini.

Očevid je započet nakon dolaska vještaka pregledom mjesta događaja, vezova, glavnog razvodnog ormara i razvodnih ormara na vezu, na koja se priključuju plovila na mrežu 220 V, a nastavljen je pregledom opožarenih plovila sljedećih dana. Pregled i ispitivanje izvršili su vještaci Centra uz pomoć inspektora zaštite od požara i očevidne ekipe, koji su prije dolaska vještaka organizirali vađenje potonulih plovila i njihovo slaganje na obali.

Izvršen je pregled mjesta događaja požara u marini, pregled i ispitivanje priključnih ormarića te pregled ostataka opožarenih plovila koji su izvađeni iz mora. Na temelju izvršenog pregleda, dobivenih obavijesti i snimki požara zaključeno je da je izbio na plovilu duljine oko $10 \mathrm{~m}$ koje se pokretalo 2 dizelska motora snage 2 × 225 kW, koje je bilo priključeno električnim kabelom na mrežni napon $220 \mathrm{~V}$, vjerojatno radi punjenja akumulatorskih baterija. Detaljnim pregledom električne instalacije i uređaja na navedenom

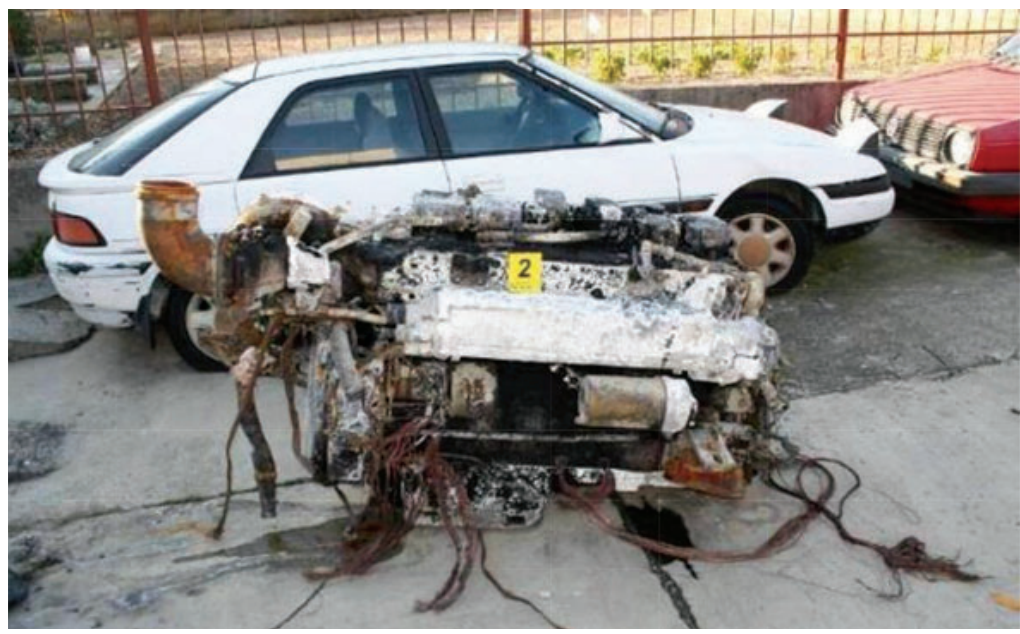

Slika 6. Brodski motor pored parkiranog vozila

Figure 6 Vessel's engine near a parked car 


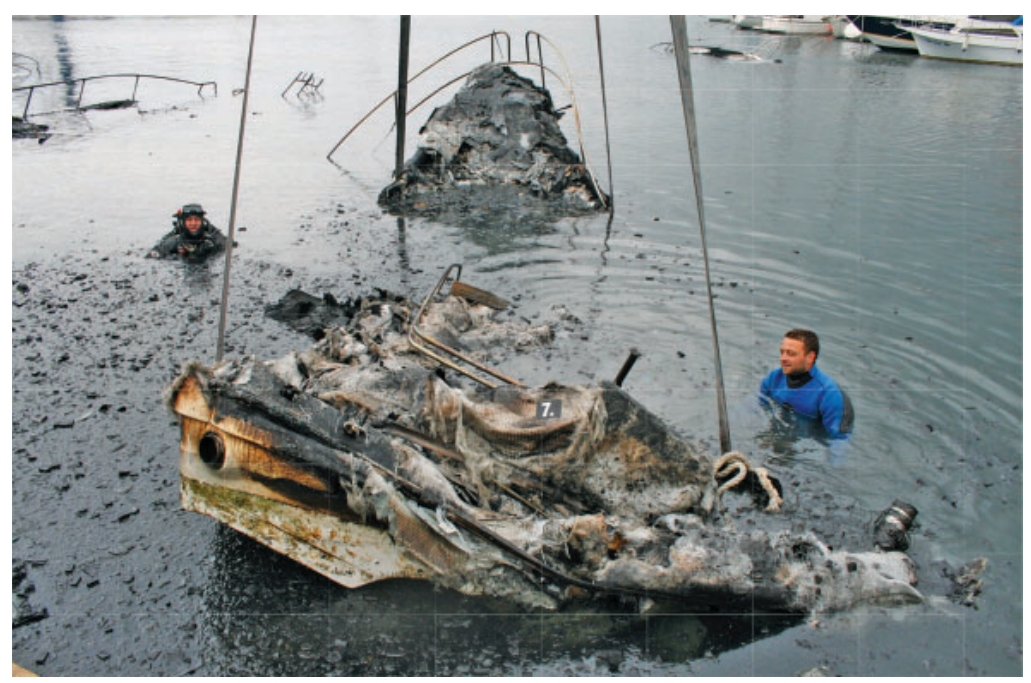

Slika 7. Vađenje opožarenog plovila iz mora Figure 7 Salvage of burnt vessel from the sea

Izvor: CFIIV „Ivan Vučetić", fotografije s očevida

plovilu, koje je izvađeno iz mora, na temelju pronađenih tragova zaključeno je da je uzrok požara najvjerojatnije kvar na električnoj instalaciji plovila. Usporednim pregledom plovila iste marke, koje se nalazilo u marini, utvrđen je vanjski izgled i interijer plovila te vrsta opreme i razvod električne instalacije koja se nalazi na njemu.

\subsection{Požar plovila u marini - slučaj 2. / Fire on vessel in marina-Case 2}

U požaru oštećeno je više plovila koja su bila vezana u marini. Na temelju izjave očevica utvrđeno je mjesto nastanka požara, odnosno plovilo na kojemu je najprije izbio požar. U požaru je gotovo u potpunosti uništeno 7 plovila, a prvo je opožareno plovilo potonulo te se radi očevida moralo izvaditi iz mora.

Prema obavijestima dobivenima na mjestu događaja požara, u motornome prostoru opožarenog plovila nalazio se aparat za automatsko gašenje požara pjenom, u pramčanome dijelu nalazila se staklena ampula tipa „,bonpet“ za automatsko gašenje požara, a u središnjem dijelu nalazila su se dva ručna aparata za gašenje požara. Ampula („,bonpet“) služi za gašenje požara tako što kada temperatura dosegne $850 \mathrm{C} \pm 50 \mathrm{C}$, ampula prsne, a njezin se sadržaj oslobodi i trenutno ugasi požar.

Prema dobivenim obavijestima od vlasnika broda, brod nije bio priključen na priključni ormarić na napon $220 \mathrm{~V}$, a priključni kabel bio je demontiran i spremljen u kabini broda. Glavna je sklopka na brodu, prema obavijestima, bila u isključenome položaju, a u tome bi slučaju pod naponom ostale samo dvije pumpe za izbacivanje vode.

Pregledom opožarenog plovila utvrđeno je da je ono gotovo u potpunosti izgorjelo cijelom dužinom do razine mora. lako je stupanj termičkih oštećenja gotovo jednak na cijelom brodu, detaljnijim pregledom uočena su najveća termička oštećenja u obliku nedostatka materijala na vanjskoj desnoj strani krmenog dijela trupa.

Do požara u marini došlo je uslijed zapaljenja jednog od vezanih brodova oko 4.30 sati. Kao posljedica širenja požara $s$ navedenog broda i njegova kontakta s ostalim brodovima na susjednom gatu, ukupno je izgorjelo sedam brodova, od čega su tri potonula, kao i sporni brod s kojega je krenuo požar. Gašenje požara bilo je otežano zbog nepostojanja hidranata u marini.

Prva opožarena motorna jahta nije bila priključena na mrežni napon od $220 \mathrm{~V}$, dok je njezina 12-voltna električna instalacija bila pod akumulatorskim napajanjem, što je utvrđeno pregledom glavne sklopke. Tragovi taljenja i zavarivanja bakrenih vodiča pronađeni su na električnoj instalaciji koja se nalazi na desnoj krmenoj strani broda te je na temelju toga i tragova termičkih oštećenja zaključeno da je do požara došlo u desnom krmenom dijelu, najvjerojatnije kao posljedica kvara na električnim instalacijama.

\section{TEHNIČKI KVAROVI NA PLOVILIMA KAO MOGUĆI UZROCI POŽARA / Technical failures on vessels as possible causes of fires}

$\mathrm{Na}$ temelju dugogodišnjeg iskustva u istraživanju uzroka požara na plovilima te vještačenja izuzetog materijala prilikom pregleda opožarenih plovila (dijelova električne instalacije i uređaja), uočeni su neki karakteristični kvarovi na njima koji su mogući uzroci požara:

Požar u motornom prostoru plovila koje je bilo na vezu u lučici izazvan je kvarom na jednoj od akumulatorskih baterija starih 5 godina, koje su napajale $24 \mathrm{~V}$ kućnu elektroinstalaciju plovila.

Požar više plovila u lučici izazvan je kvarom na električnom kabelu koji vodi od akumulatora do elektropokretača izvanbrodskog motora.

Požar više plovila u marini izazvan je tehničkim kvarom na elektroinstalaciji $220 \mathrm{~V}$ jednog od plovila, koje je radi punjenja baterija bilo priključeno kabelom na mrežu na obali.

Požar većeg broja plovila na suhom vezu u marini izazvan je tehničkim kvarom na $12 \mathrm{~V}$ elektroinstalaciji jednog od plovila, koje je imalo sustav za napajanje električnom energijom s pomoću solarnih panela radi punjenja baterija. Do požara u marini došlo je zbog tehničkog kvara na 12-voltnoj instalaciji plovila, koja je ostala pod akumulatorskim napajanjem.

Kvar na električnoj instalaciji u motornom prostoru glisera najvjerojatnije je nastao kao posljedica nepravilne izvedbe elektroinstalacije koja se napajala iz baterija.

Požar na plovilu izbio je zbog kvara na elektromotoru ventilatora klimatskog uređaja, koji je bio u funkciji kada je plovilo bilo priključeno na napajanje $220 \mathrm{~V}$ u marini. 


\section{REZULTATI ISTRAŽIVANJA POŽARA I PREPORUKE ZA KORIŠTENJE INSTALACIJAMA NA PLOVILIMA / Results of fire investigations and recommendations for working on vessels' electrical installations}

Do požara plovila koja su u marinama često dolazi zbog nepridržavanja pravila da se plovila koja su na vezu ne priključuju na električnu mrežu radi punjenja akumulatora i slično, odnosno uslijed ostavljanja plovila pod akumulatorskim napajanjem neisključivanjem glavne sklopke na plovilu kada korisnik nije na njemu dulje vrijeme. Nakon nekoliko požara na kojima je utvrđeno da je mogući uzrok nepridržavanje navedenih pravila, postrožena su pravila u većini marina.

Također je važno pridržavanje pravila da plovila na suhom vezu, kada vlasnik nije dulje vrijeme na plovilu, ne ostaju priključena na mrežno napajanje $220 \mathrm{~V}$, koje je omogućeno priključkom električnog kabela na razvodni ormarić na doku. To bi trebali kontrolirati djelatnici marine (mornari) prilikom obilaska dokova i isključiti napajanje plovila koja zateknu priključena na razvodne ormariće.

U praksi moguće je da istražitelji ne mogu utvrditi točan uzrok požara na plovilu. Obično se radi o slučaju kada je u požaru došlo do gotovo potpunog uništenja plovila ili prilikom potonuća plovila u more nije bilo moguće pronaći i izvaditi sve dijelove plovila koji su važni za utvrđivanje uzroka požara.

\section{ZAKLJUČAK / Conclusion}

Vještaci Centra "Ivan Vučetić" sudjeluju u radu očevidnih ekipa MUP-a prilikom utvrđivanja uzroka požara pri najvećim i najsloženijim požarima, pri čemu je njihova zadaća utvrđivanje mjesta na kojima je izbio požar i uzroka požara. Vještačenje uzroka požara multidisciplinarno je vještačenje u kojemu po potrebi sudjeluju vještaci Centra kemijske, elektrotehničke i strojarske struke, od kojih svaki pregledava mjesto događaja tražeći karakteristične tragove, a zajedno utvrđuju mjesto nastanka požara.
Prilikom pregleda mjesta događaja potrebna je dobra suradnja između vještaka i očevidne ekipe, istražitelja koji prikupljaju obavijesti u vezi s požarom i vode zapisnik o očevidu te kriminalističkih tehničara koji fotografiraju mjesto događaja, utvrđuju pronađene tragove i izuzimaju materijal koji se pohranjuje u korporu ili šalje na vještačenje. Radi dobivanja pomoći prilikom očevida, prema potrebi uključuju se vatrogasci, ronioci, inspektori zaštite od požara te djelatnici brodogradilišta ili marine.

U radu je na primjerima iz prakse prikazan rad vještaka Centra prilikom utvrđivanja uzroka požara na plovilima. Iznesene su metode utvrđivanja mjesta nastanka i uzroka požara te je ukazano na neke karakteristične kvarove koji mogu dovesti do požara.

\section{LITERATURA / References}

[1] CFIIV „Ivan Vučetić“ (2001-2018). Zapisnici o vještačenju i fotografije s očevida.

[2] Mileusnić, E. (1999.) Mjere sigurnosti i zaštite na radu kod primjene električne energije. Zagreb: ZIRS.

[3] Papić, N. (2013). „Obrazac za pregled električnih instalacija i uređaja kod požara plovila“. CFIIV „Ivan Vučetić".

[4] Papić, N. (2013). „Pregled i ispitivanje električnih instalacija i uređaja u plovilu i utvrđivanje mjesta nastanka i uzroka požara“. CFIIV „Ivan Vučetić, radne upute.

[5] Papić, N. (2015). „Tehnička vještačenja uzroka požara na vozilima i plovilima“. Policijska akademija, prezentacija za Tečaj za kriminalističke tehničare.

[6] Papić, N. (2016). „Elektrotehnička vještačenja“. CFIIV „Ivan Vučetić“, prezentacija.

[7] Papić, N., Barbarić, F. (2016). Tehnička vještačenja. http://www.forenzika. hr/973.aspx.

[8] Papić, N. (2017). „Nesreće na radu uzrokovane udarom električne struje“. Sigurnost, br. 3, str. 245-253. https://doi.org/10.31306/s.59.3.6

[9] Papić, N. (2017). „Vještačenje požara u objektima zbog tehničkih kvarova“. $E G E$, br. 1, str. 104-106

[10] Papić, N. (2018).,Vještačenje uzroka požara“. Policija i sigurnost, br. 3, str. 267-280.

[11] Papić, N., Marcikić, M. (2018). „Vještačenje nesreća uzrokovanih strujnim udarom". Sigurnost, br. 2, str. 149-158. https://doi.org/10.31306/s.60.2.5

[12] Srb, V. (1991). Električne instalacije i niskonaponske mreže. Zagreb: Tehnička knjiga.

[13] Zdenković, J. (2016). „Priključak na kopno“. Burza nautike, 3. svibnja 2016. https://www.burzanautike.com/hr/prikljucak_na_kopno/4051/25. 